\title{
Effect of three different anti-mycotoxin additives on broiler chickens exposed to aflatoxin $B_{1}$
}

\author{
Efecto de tres diferentes aditivos anti-micotoxinas en los pollos de engorde \\ expuestos a aflatoxina $\mathrm{B}_{1}$ \\ AA Oliveira ${ }^{\mathrm{a}, \mathrm{e}}$, KM Keller ${ }^{\mathrm{b}}$, MV Deveza ${ }^{\mathrm{a}}$, LAM Kellera, EO Dias ${ }^{\mathrm{a}}$, BJ Martini-Santos ${ }^{\mathrm{c}}$, \\ DFGM Leitão ${ }^{\mathrm{a}, \mathrm{e}}$, LR Cavaglieri ${ }^{\mathrm{d}, \mathrm{f}}$, CAR Rosa ${ }^{\mathrm{a}, \mathrm{e}}$ \\ anstituto de Veterinária, Universidade Federal Rural do Rio de Janeiro, Rio de Janeiro, Brazil. \\ ${ }^{\text {b}}$ Departamento de Medicina Veterinária Preventiva, Escola de Veterinária, Universidade Federal de Minas Gerais, \\ Minas Gerais, Brazil. \\ ${ }^{c}$ Faculdade de Medicina Veterinária de Valença, Centro de Ensino Superior de Valença, Fundação Dom André Arcoverde, \\ Rio de Janeiro, Brazil. \\ dDepartamento de Microbiología e Inmunología, Universidad Nacional de Río Cuarto, Río Cuarto, Argentina.

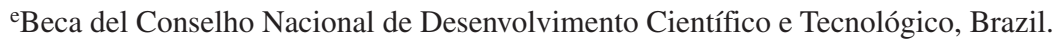 \\ ${ }^{\mathrm{f}}$ Miembro del Consejo Nacional de Investigaciones Científicas y Técnicas, Buenos Aires, Argentina.
}

\begin{abstract}
RESUMEN
El crecimiento de hongos filamentosos en alimentos puede implicar, aparte de deterioro, la producción de micotoxinas que causan pérdidas económicas en la industria avícola, debido a la disminución de la productividad y aumento de susceptibilidad a enfermedades en aves de corral. Adsorbentes basados en la pared celular de la levadura Saccharomyces cerevisiae, que contiene glucomanano esterificado, son una alternativa para reducir la biodisponibilidad de las micotoxinas. Este estudio comparó in vitro e in vivo el rendimiento de tres nuevos aditivos antimicotoxinas (AMA) basados en la pared celular de la levadura de Saccharomyces cerevisiae. El proceso de adsorción se cuantificó in vitro, y los datos obtenidos cuando se representa con el modelo matemático de la ecuación de Hill indicaron un proceso cooperativo. Tres diferentes AMA fueron probados por su capacidad para reducir los efectos de las aflatoxinas. La adición de $1 \mathrm{mg} \mathrm{kg}^{-1}$ de aflatoxina $\mathrm{B}_{1}$ en la dieta de pollos de engorde afectó negativamente los parámetros de rendimiento, con aumento del peso del hígado, degeneración grasa y necrosis hepática. La adición de dos tipos diferentes de AMA (0,2\%) revirtió tales efectos, y uno mostró un efecto sinérgico con aflatoxina $\mathrm{B}_{1}$. Concluyendo, AMA 1 y 2 son aditivos con buen potencial para su aplicación en producción animal. Los ingredientes del AMA 3 deben ser reexaminados solo por su capacidad de adsorción. Estos son los primeros datos en Brasil correspondientes a aditivos antimicotoxinas por medio del estudio de isotermas de adsorción. Debido a que las características beneficiosas son dependientes de la cepa, este estudio sugiere dos nuevas alternativas prometedoras para mejorar el problema de las micotoxinas.
\end{abstract}

Palabras clave: hongos, micotoxinas, pollo, glucomanano.

\section{SUMMARY}

The growth of filamentous fungi on food often causes, aside from its deterioration, the mycotoxin production which determines economic losses in poultry industry, such as decreased productivity and injuries on poultry's carcass. Adsorbents based on yeast cell wall from Saccharomyces cerevisiae, which contain esterified glucomannan, are an alternative to reduce the mycotoxins bioavailability. The aim of this study was to compare in vitro and in vivo the performance of new three anti-mycotoxin additives (AMA) based on yeast cell wall from Saccharomyces cerevisiae. The adsorption process was quantified in vitro, and the data obtained when plotted with Hill's equation indicated a cooperative process. Then, the three different AMA were tested for its ability to reduce the effects of aflatoxins in the diet of growing broiler chickens. The addition of $1 \mathrm{mg} \mathrm{kg}^{-1}$ aflatoxin $\mathrm{B}_{1}$ to the diets of broilers caused a negative change on the performance parameters besides increasing liver weight, fatty degeneration and liver necrosis. The addition of two different kinds of AMA $(0.2 \%)$ could reverse such effects. In conclusion, AMA 1 and 2 are additives with good potential for application on animal production. The AMA 3 ingredients must be re-tested alone for its adsorption capacity. These are the first data reported from Brazil anti-mycotoxin additives with preliminary isothermal analysis. Since beneficial characteristics of $S$. cerevisiae cell wall in animal industry are strain dependent, this study suggests two new promising alternatives to ameliorate mycotoxin problem.

Key words: fungi, mycotoxin, broiler, glucomannan.

Accepted: 04.12.2014.

* Avenida Antônio Carlos nº 6627, Belo Horizonte, Minas Gerais, Brazil; kelly.medvet@gmail.com 


\section{INTRODUCTION}

Filamentous fungi growth often causes food deterioration and quality loss as well as mycotoxin production by several fungal species. Mycotoxins are toxic substances to humans and animals that cause major economic loss in animal production (Manafi et al 2012). Aflatoxins (AF) are mainly produced by two fungal species: Aspergillus flavus and Aspergillus parasiticus, which naturally grow in common feed ingredients used in poultry rations, such as corn and wheat. The major compound types of aflatoxins are identified as aflatoxin $\mathrm{B}_{1}\left(\mathrm{AFB}_{1}\right)$, the most potent toxigen, followed by $\mathrm{B}_{2}, \mathrm{G}_{1}$ and $\mathrm{G}_{2}$ (Rawal et al. 2010).

Aspergillus flavus produces only aflatoxin $\mathrm{B}$, and sometimes cyclopiazonic acid (CPA), while A. parasiticus produces aflatoxins B and $\mathrm{G}$, but never produces CPA (Pitt 1993). This simple situation was complicated by taxonomic discoveries. In 1987, A. nomius, a species closely related to A. flavus, but producing sclerotia in the form of small bullets, distinct of the large spherical sclerotia produced by most isolates of $A$. flavus. This species is also distinct from A. flavus for the production of both aflatoxins B and $\mathrm{G}$ (Kurtzman et al 1987). The second new species closely related to A. nomius has been described in 2001 and named $A$. bombycis. Differences in DNA and also the rate of growth at $37{ }^{\circ} \mathrm{C}$ are characteristics that make possible to difference these two species. Likely A. nomius, A. bombycis produces aflatoxins B and G (Peterson et al 2001). The species A. ochraceoroseus described in 1978, was shown to be another aflatoxin producer (Bartoli and Maggi 1978). Two aflatoxin producers isolated in Japan, which initially were classified as atypical $A$. tamarii were described in 1996 as A. pseudotamarii. Similarly to A. flavus, this species produces aflatoxins B and CPA but differs due to the production of orange brown conidia (Ito et al 2001). In genetic studies of populations of A. flavus, new discoveries showed that $A$. flavus isolated from peanut fields in Australia consisted of two distinct subgroups, Group I and Group II (Geiser et al 1998). Other studies confirmed that A. flavus Group II comprises a distinct species, which were described as A. australis (Geiser et al 2000). Unlike any other known species, A. australis also produces aflatoxins B and G and CPA. It appears that this occurs almost exclusively in the southern hemisphere, being found in countries such as Argentina, Australia, Indonesia and South Africa. This new information, although complex, should not obscure the importance of the oldest species. Evidence indicates that A. flavus and A. parasiticus are responsible for the large majority of aflatoxins found in foods and feeds worldwide. The other species, only $A$. australis, which seems to be widespread in the southern hemisphere and is common in Australian soils peanut, can also be an important source of aflatoxins in some countries.

The presence of AF in the poultry industry produces economic loss through poor growth and feed conversion, increased mortality, leg problems, and carcass condemnation.
Aflatoxins cause a wide range of metabolic changes and are associated with liver damage, reduced digestive enzyme activity, and immunosuppression (Giacomini et al 2006, Salim et al 2011).

Several reports of poultry feed contamination with AF and/or aflatoxigenic fungi have emphasised the importance of studies to determine alternatives for aflatoxicosis prevention in the poultry industry (Manafi et al 2012, Rossi et al 2013). Anti-mycotoxin additives (AMA) define a group of products that when added to animal feed are capable of adsorbing, inactivating, or neutralising mycotoxins in the gastrointestinal tract. Examples of these products are adsorbents based on yeast cell wall (YCW) preparations, wich most times are regarded as safe. These types of additives, which are mainly derivatives of the yeast Saccharomyces cerevisiae, have esterified glucomannans that are able to efficiently adsorb several mycotoxins (Çelik et al 2003, Manafi et al 2012). YCW additives can also stimulate the immune system and contribute to the integrity of the intestinal mucosa as prebiotics, which improve animal health (Flemming and Freitas 2005, Keller et al. 2012). A prebiotic is a selectively fermented ingredient that results in specific changes in the composition and/or activity of the gastrointestinal microbiota, thus conferring benefit(s) upon host health (Gibson et al 2010). YCW additives are strain-dependent and should be tested individually for their beneficial properties. They differ in their effectiveness to sequester $\mathrm{AFB}_{1}$ in feed and, consequently, in reducing aflatoxicosis in chickens. Yiannikouris et al (2003) proposed that the glucan portion of the YCW is the active component that interacts with the mycotoxin molecule. Aravind et al (2003) suggested that the addition of dietary glucomannans is effective in broiler chickens to counteract the in vivo toxic effects of feed naturally contaminated with mycotoxins. Thus, the aim of this study was to evaluate the AF adsorption capacity by three AMAs bound to YCW and to compare their performance in broiler chickens exposed to AF.

\section{MATERIAL AND METHODS}

\section{CHEMICAL REAGENTS AND BIOLOGICAL MATERIAL}

Stock methanol solutions containing $5 \mathrm{mg}$ of $\mathrm{AFB}_{1}{ }^{1}$ (purity: $99.5 \pm 0.5 \%$ ) were prepared. The actual concentration of the toxin in each solution was determined by the Association of Official Analytical Chemists (AOAC) procedure (AOAC 1990). All in vitro and in vivo assays were performed with $\mathrm{AFB}_{1}$ only because it is the most toxic and frequent. The three AMAs were provided by a Brazilian company. The AMA-1 and the AMA-2 were made of S. cerevisiae YCW (100\%). The proximate chemical composition of AMA-1 was $5 \%$ moisture, $25 \% \beta$ glucans, $19 \%$ mannans, $27 \%$ proteins, $1 \%$ phosphorus, $20 \%$ fats, $3 \%$ ash; and the AMA-2 was 5\% moisture, $21 \% \beta$ glucans,

\footnotetext{
Biopure ${ }^{\circledR}$ Solid Standards.
} 
$17 \%$ mannans, $29 \%$ proteins, $1 \%$ phosphorus, $23 \%$ fats, $4 \%$ ash. The AMA-3 was a mixture of S. cerevisiae YCW $(100 \%)$ and $30 \%$ sodium bentonite (mineral adsorbent); the final proximate chemical composition of AMA-3 was $15 \% \beta$ glucans, $10 \%$ mannans, $22 \%$ proteins, $1 \%$ phosphorus, $15 \%$ fats, $23 \% \mathrm{SiO}_{2}, 12 \% \mathrm{Al}_{2} \mathrm{O}_{3}, 2 \% \mathrm{CaO}$ and traces of $\mathrm{MgO}, \mathrm{Na}_{2} \mathrm{O}, \mathrm{Fe}_{2} \mathrm{O}_{3}, \mathrm{P}_{2} \mathrm{O}_{5}, \mathrm{~K}_{2} \mathrm{O}$. All organic solvents were of HPLC grade ${ }^{2}$. The water used in all of the experiments was prepared by processing deionised water through a Milli-Q system.

\section{ADSORPTION EXPERIMENTS}

Working solutions containing 3.84, 2.58, 1.84, 1.21, and $0.52 \mu \mathrm{g}$ of $\mathrm{AFB}_{1} \mathrm{~mL}^{-1}$ were prepared from the stock solution. One concentration $\left(2 \mathrm{mg} \mathrm{mL}^{-1}\right)$ at $2 \mathrm{pH}$ levels (3 and 6) of the 3 AMAs were obtained and used for the in vitro assays. The AMAs were resuspended in a solution at $\mathrm{pH} 3^{3}$ and in a solution at $\mathrm{pH} 6^{4}$ for subsequent use in the adsorption tests. The $\mathrm{pH}$ was confirmed using a $\mathrm{pH}$ meter $^{5}$, and the corresponding $\mathrm{pH}$ was adjusted using 0.2 $\mathrm{M}$ hydrochloric acid or $0.1 \mathrm{M}$ sodium hydroxide solutions.

The AMAs in solution (pH 3 and 6) disposed into plastic microtubes were incubated with the mycotoxin for $1 \mathrm{~h}$, which is the time needed to reach the adsorption equilibrium at $37^{\circ} \mathrm{C}$, at $150 \mathrm{rpm} \mathrm{min}-1$ in a refrigerated centrifuge $^{6}$. Immediately after reaching equilibrium, the extracts were precipitated under agitation $(13000 \mathrm{rpm}$ $\min ^{-1}$ ) for $10 \mathrm{~min}$ at $37^{\circ} \mathrm{C}$. A control treatment without AMA was employed for each experiment to investigate any possible non-specific binding of $\mathrm{AFB}_{1}$. Each experiment was performed in triplicate. The final extract was analysed by high performance liquid chromatography (HPLC). The amount of $\mathrm{AFB}_{1}$ linked to the sorbent was obtained by calculating the difference between the initial and the final amounts of aflatoxin in the supernatant.

\section{DETECTION AND QUANTIFICATION OF AFLATOXIN}

The HPLC apparatus was a Shimadzu ${ }^{\circledR}$ chromatograph with a UV visible detector (excitation $\lambda 360 \mathrm{~nm}$ ) and a C18 column $(250 \mathrm{~mm} \times 10 \mathrm{~mm} \times 5 \mu \mathrm{m})$. The mobile phase was injected at $1.0 \mathrm{~mL} \mathrm{~min}-1$ and consisted of the following isocratic system: $65 \%$ methanol:acetonitrile (90:10) and $35 \%$ water. The AF was quantified on the basis of the HPLC response compared with the AF standard. The detection limit of the method was $1 \mathrm{ng} \mathrm{g}^{-1}$.

\footnotetext{
2 Vetec Química Fina/Sigma-Aldrich, Brazil.

3 Recipe: $50 \mathrm{~mL}$ of $0.2 \mathrm{M}$ potassium chloride and $13 \mathrm{~mL}$ of $0.2 \mathrm{M}$ hydrochloric acid, adjusted for $\mathrm{pH} 3$.

4 Recipe: $100 \mathrm{~mL}$ of $0.1 \mathrm{M}$ potassium phosphate monobasic and 11.2 $\mathrm{mL}$ of $0.1 \mathrm{M}$ sodium hydroxide, adjusted for $\mathrm{pH} 6$.

5 Gehaka ${ }^{\circledR}$ model PG 1800, Brazil.

$6 \quad$ Sigma ${ }^{\circledR}$ model 3K-30, UK.
}

\section{DATA PROCESSING AND CURVE FITTING}

Curves representing the amount of bound $\mathrm{AFB}_{1}$, as a function of the amount of added $\mathrm{AFB}_{1}$, were plotted according to the Hill equation. The Hill equation, unlike other models, integrates a factor accounting for the sigmoid shape of the curve, which indicates a cooperative interaction between the toxin and the binder. Thus, the Hill model provides comprehensive information explaining the biological, physical, and chemical analysis of the adsorption process (Yiannikouris et al 2003). The Hill mathematical equation, $\left(\Gamma=\left(\Gamma_{\max } \cdot x^{n}\right) / k_{d}+x^{n}\right)$, where $k_{d}$ is the dissociation constant, $x$ is the equilibrium concentration of the solute, and $n$ is the Hill coefficient index or coefficient for the cooperative process, was used to characterize the adsorption of $\mathrm{AFB}_{1}$ in phosphate buffer solution (pH 3 and 6). Origin ${ }^{\circledR}$ 8.0 software was used to plot the experimental data, set up the regression curve (curve fitting), and calculate the statistical data in the binding capacity tests.

\section{AFLATOXIN PRODUCTION AND ANALYSIS FOR FEEDING TRIALS}

Aflatoxins were produced via the fermentation of rice by A. parasiticus (NRRL 2999) by using the method described by Shotwell et al (1966) with minor modifications. The AF content was extracted and purified through a MycoSep ${ }^{\circledR}$ 226 AflaZon column according with the manufacturer's ${ }^{7}$ instructions, and then quantified by HPLC. The AF content in the milled rice was $86 \% \mathrm{AFB}_{1}, 5 \% \mathrm{AFG}_{1}, 6 \% \mathrm{AFB}_{2}$, and $3 \% \mathrm{AFG}_{2}$. The milled rice was incorporated into the basal diet through a $\mathrm{Y}$ type mixer with a capacity of 15 $\mathrm{kg}$. The AF of mixture was extracted an purified according the same methodology to provide the desired level of 1 $\mathrm{mg}$ of $\mathrm{AFB}_{1} \mathrm{~kg}^{-1}$ of diet.

\section{EXPERIMENTAL DESIGN AND BIRDS}

Cobb-type mailer broiler chicks (age $=1 \mathrm{~d}, \mathrm{n}=576$ ) were obtained from a commercial hatchery ${ }^{8}$. Individually weighed chicks were divided at random into 8 groups: T01 (AF-free diet, or basal diet (BD)), T02 (BD + 0.2\% AMA1), T03 (BD + 1 mg.kg-1 AF), T04 (BD + $1 \mathrm{mg} \cdot \mathrm{kg}^{-1} \mathrm{AF}+$ $0.2 \%$ AMA-1), T05 (BD + 0.2\% AMA-2), T06 (BD + 1 $\mathrm{mg} \cdot \mathrm{kg}^{-1} \mathrm{AF}+0.2 \%$ AMA-2), $\mathrm{T} 07$ (BD + 0.2\% AMA-3) and $\mathrm{T} 08\left(\mathrm{BD}+1 \mathrm{mg} \cdot \mathrm{kg}^{-1} \mathrm{AF}+0.2 \% \mathrm{AMA}-3\right)$. Chickens were allowed access to the diets and water ad libitum. The feed used was a commercial diet called FFC002-starter ${ }^{9}$, whose composition is listed in table 1. The starter/grower basal diet were supplemented with amino acids, minerals,

\footnotetext{
Romer Labs ${ }^{\circledR}$.

8 Reginaves Ind. e Com. de Aves Ltda, Rio Claro/RJ-Brazil.

9 No Ramo Indústria e Comércio de Alimentos Ltda, São José do Vale do Rio Preto/RJ-Brazil.
} 
and vitamins at levels recommended by the National Research Council. The basal diets were tested, using the same methodology described for the milled rice, for possible residual AF before feeding, and there were no detectable $\mathrm{AF}$ levels present. Chickens were monitored daily for signs of morbidity and mortality. The animals were divided into 72 per treatment group (9/cage, 36/block, and 2 blocks/ treatment). The clinical observation of the animals and the measurement of the environmental temperature were done three times a day. The effect of the additives on aflatoxicosis was determined by measuring body weight (BW), body weight gain (BWG), feed consumption (FC), and feed-to-gain ratio (FGR) at 14 and 21 days old. The design of the study followed the recommendations from the Brazilian Ministry of Agriculture, Livestock and Supply for the registration of products intended as AMAs, and all procedures were performed according to the recommendations by the Brazilian National Council for the Control of Animal Experimentation (UFRRJ Protocol n 367).

\section{PATHOLOGICAL EXAMINATION AND HISTOPATHOLOGY}

All the animals were weighed before being sacrificed. A detailed necropsy was then conducted. The liver was removed and weighed. The relative organ weights (weight of organ per $100 \mathrm{~g}$ live body weight) were calculated. Livers were macroscopically analysed and fixed in $10 \%$ neutral buffered formalin for $24 \mathrm{~h}$ and then $70 \%$ alcohol. Fixed tissues were trimmed, embedded in paraffin, and stained with hematoxylin and eosin for histopathological examination. The score attributed to evaluate the macroscopical lesions were $(-)=$ no changes, liver unremarkable; $(+)=$ mild aflatoxicosis lesions; $(++)=$ moderate aflatoxicosis lesions; $(+++)=$ severe aflatoxicosis lesions.

\section{STATISTICAL ANALYSIS}

Data were evaluated by ANOVA $(\mathrm{P} \leq 0.05)$ for a complete randomised design using the general linear models procedure of SAS software, version 9.1.3. In all cases, all variables and all possible interactions were tested. When the ANOVA showed significance, Tukey-Kramer's significant-difference test was applied.

\section{RESULTS}

The isotherms for $\mathrm{AFB}_{1}$ binding to the AMAs are displayed in figure 1. The isotherms were fit to the Hill mathematical equation to determine values for the dissociation constant $\left(k_{d}\right)$, association constant $(\beta)$, maximum adsorption capacity $\left(\Gamma_{\max }\right)$, and number of sites for the cooperativity (n), as shown in table 2 . All isotherms displayed an $\mathrm{S}$ shape pattern that could be adjusted to the Hill model. This model has been previously proposed to explain the shape of adsorption isotherms on YCWs and extracts derived from them (Yiannikouris et al 2003,
Table 1. Bromatological composition of feed trials diet. Composición bromatológica de los ensayos in vivo.

\begin{tabular}{lcc}
\hline Macro Ingredients & Unit & $\begin{array}{c}\text { Starter/Grower } \\
(1-21 \text { days })\end{array}$ \\
\hline Milled Corn CP 8,0\% & $\mathrm{g}$ & 641,7 \\
Soybean Meal 46\% / 80\% & $\mathrm{g}$ & 289,0 \\
Meat Meal 40\% & $\mathrm{g}$ & 53,3 \\
Sodium Chloride & $\mathrm{g}$ & 2,6 \\
Calcite 38\% & $\mathrm{g}$ & 4,3 \\
& & \\
\hline Micro Ingredients & Unit & Starter/Grower \\
\hline Premix Vitamin/Mineral & $\mathrm{g}$ & 4,0 \\
Baking Soda & $\mathrm{g}$ & 1,4 \\
DL- Methionine & $\mathrm{g}$ & 1,1 \\
L- Lysine & $\mathrm{g}$ & 2,6 \\
Total (Macro + Micro) & $\mathrm{g}$ & 1000 \\
\hline
\end{tabular}

$2004^{\mathrm{a}}, 2004^{\mathrm{b}}$ ). In one of these studies, Yiannikouris et al (2004') found that $6,177 \mu \mathrm{g} \mathrm{mL}^{-1}$ of $\mathrm{AFB}_{1}$ was adsorbed by $100 \mu \mathrm{g} \mathrm{mL}^{-1}$ of YWC, values greater than the present study. Regarding the maximum coating $\left(\Gamma_{\max }\right)$ obtained by the YCWs with $\mathrm{AFB}_{1}$, these values were higher of those obtained by Galvano et al (1997) with activated carbon $\left(0.12 \mathrm{~g} \mathrm{~g}^{-1}\right)$ and Dakovic et al (2008) with copper modified montmorillonite $\left(0.066 \mathrm{~g} \mathrm{~g}^{-1}\right)$ as adsorbents. In the present study, all $\mathrm{AMAs}$ adsorbed $\mathrm{AFB}_{1}$ at simulated gastrointestinal $\mathrm{pH}$ conditions. These results agree with those reported by Yiannikouris et al $\left(2004^{\mathrm{a}}\right)$, who attributed the adsorption to the presence of $\beta$-glucans in the walls. The tested YCWs differ in their chemical compositions and it is known that the three-dimensional structure of the polysaccharides that constitute the YCW allows the adsorption of mycotoxins or its metabolic derivatives. Yeasts cell wall are composed mainly by polysaccharides, proteins and lipids that offer numerous functional groups for the interaction, such as carboxyl, hydroxyl, phosphate and amine groups, as well as hydrophobic adsorption sites, such as aliphatic chains and aromatic carbon rings (Jouany et al 2005, Ringot et al 2005). For these reasons, the efficiency to adsorb mycotoxins is a complex function of the following three factors: chemical structure of the toxin, adsorbent composition and the $\mathrm{pH}$ of the medium. These results suggest that they are future candidates for in vivo adsorption assays. In vitro evaluations could be useful as a screening method because they provide a better idea of the affinity for the toxins under simulated in vivo conditions, in a relatively short time and with a small cost. Nevertheless, in vivo studies always should be conducted to determine the detoxification ability on animal production, and therefore the in vivo assays are the focus of the present work. 

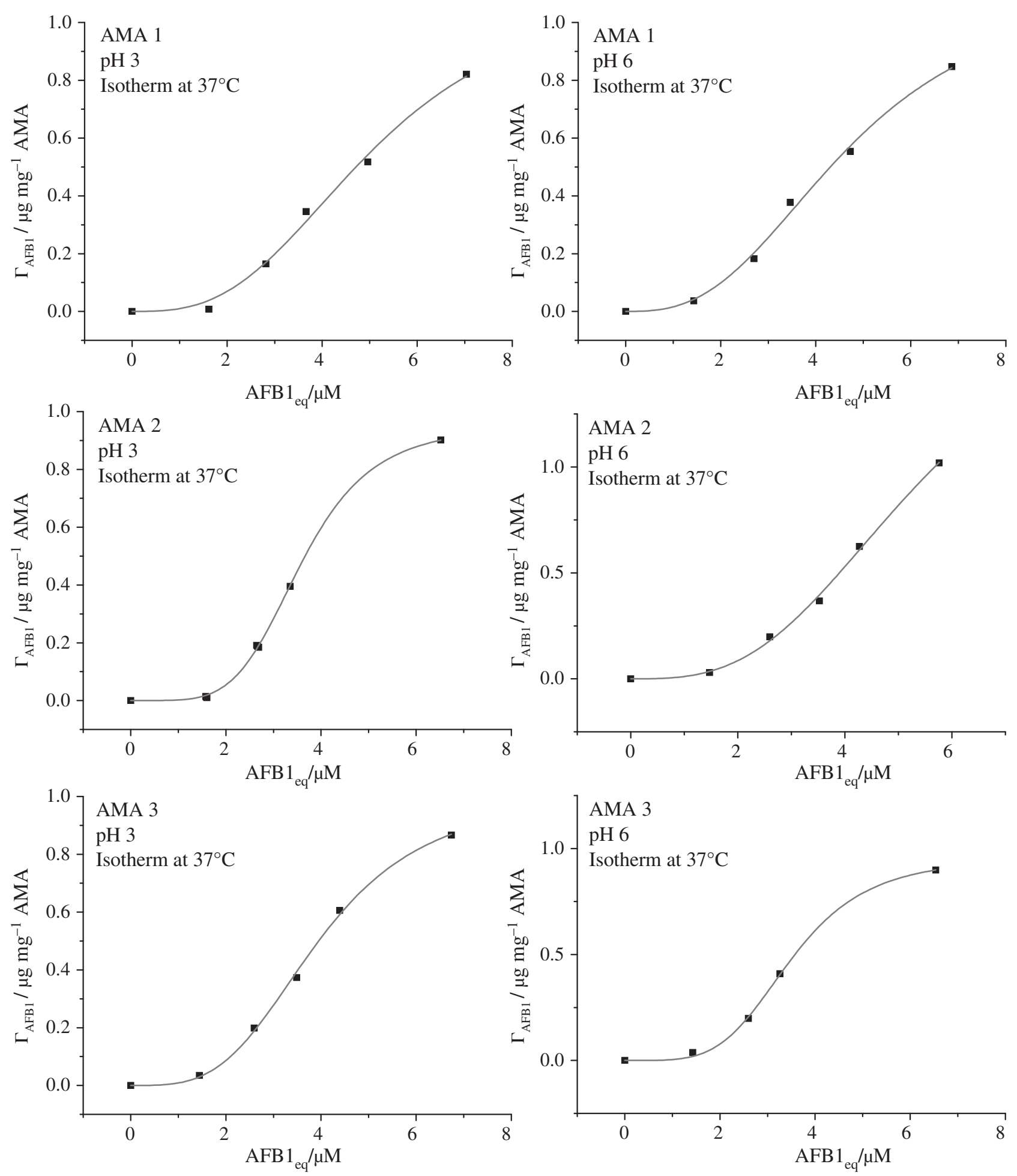

Figure 1. Adsorption isotherms of $\mathrm{AFB}_{1}$ to the sorbents.

Isotermas de adsorción de $\mathrm{AFB}_{1}$ y los AMAs analizados.

About BW, BWG, FC and FCR, the statistical analysis indicated that all the variables presented statistical significance (p-values less than 0.05), as well as their interaction. Thus, it is concluded that there is a fixed effect of $\mathrm{AFB}_{1}$, AMA and time, but also the different combination of these factors have different influence. The values of BW and BWG are shown in table 3 . After $14 \mathrm{~d}$, broiler chickens exposed to the AF treatment (T03) had a mean BW (397.92 g) that was significantly lower than the control value $(428.85 \mathrm{~g})$. The results showed that AMA-3 plus AF 
Table 2. Fitting parameters of adsorption isotherms for $\mathrm{AFB}_{1}$ and the AMAs analysed.

Los parámetros de ajuste de las isotermas de adsorción de $\mathrm{AFB}_{1}$ y los $\mathrm{AMAs}$ analizados.

\begin{tabular}{cccccccc}
\hline AMA & $\mathrm{pH}$ & $k_{d}(\mu \mathrm{M})$ & $10^{-6} \mathrm{~b}\left(\mathrm{M}^{-1}\right)$ & $\begin{array}{c}\Gamma_{\max } \\
(\mu \mathrm{g} \mathrm{mg})\end{array}$ & $\mathrm{n}$ & $\mathrm{N}^{*}$ & $\mathrm{R}^{2}$ \\
\hline 1 & 3 & $5.124 \pm 1.013$ & $0.195 \pm 0,198$ & $1.138 \pm 0.278$ & $2.907 \pm 0.697$ & 5 & 0.986 \\
& 6 & $4.727 \pm 0.761$ & $0.212 \pm 0,161$ & $1.146 \pm 0.212$ & $2.744 \pm 0.543$ & 5 & 0.990 \\
2 & 3 & $3.590 \pm 0.048$ & $0.279 \pm 0,013$ & $0.953 \pm 0.014$ & $4.805 \pm 0.206$ & 8 & 0.999 \\
& 6 & $5.459 \pm 1.076$ & $0.183 \pm 0,197$ & $1.887 \pm 0.558$ & $3.032 \pm 0.512$ & 5 & 0.995 \\
3 & 3 & $3.972 \pm 0.175$ & $0.252 \pm 0,044$ & $1.009 \pm 0.057$ & $3.453 \pm 0.349$ & 5 & 0.997 \\
& 6 & $3.508 \pm 0.147$ & $0.285 \pm 0,042$ & $0.960 \pm 0.043$ & $4.334 \pm 0.663$ & 4 & 0.997 \\
\hline
\end{tabular}

$k_{d}=$ dissociation constant.

$\beta=$ association constant.

$\Gamma_{\max }=$ maximum adsorption capacity.

$n=$ number of sites for the cooperative process

$\mathrm{N}=$ number of points on the curve.

* Each point is the mean of a triplicate.

Table 3. Effects of treatments on temporal body weight and body weight gain.

Efecto de los tratamientos sobre el peso corporal temporal y el aumento de peso corporal.

\begin{tabular}{|c|c|c|c|c|c|}
\hline \multicolumn{2}{|c|}{ Treatment } & \multicolumn{2}{|c|}{ Body weight (g) } & \multicolumn{2}{|c|}{ Body weight gain (g) } \\
\hline $\mathrm{AF}$ & AMA & $14 \mathrm{~d}$ & $21 d$ & $14 \mathrm{~d}$ & $21 \mathrm{~d}$ \\
\hline - & - & $428.85 \pm 23.74$ & $720.97 \pm 26.38$ & $277.03 \pm 26.04$ & $292.12 \pm 37.14$ \\
\hline+ & - & $397.92 \pm 14.53$ & $727.68 \pm 15.68$ & $248.04 \pm 7.85$ & $329.77 \pm 5.75$ \\
\hline- & 1 & $409.72 \pm 14.47$ & $735.78 \pm 21.26$ & $253.92 \pm 10.08$ & $326.06 \pm 9.63$ \\
\hline+ & 1 & $409.63 \pm 24.63$ & $726.52 \pm 14.74$ & $258.48 \pm 17.90$ & $316.88 \pm 34.26$ \\
\hline- & 2 & $414.59 \pm 16.36$ & $737.99 \pm 21.16$ & $261.64 \pm 16.00$ & $323.39 \pm 25.06$ \\
\hline+ & 2 & $408.76 \pm 35.46$ & $735.04 \pm 26.98$ & $259.67 \pm 28.26$ & $326.28 \pm 15.09$ \\
\hline- & 3 & $419.08 \pm 48.87$ & $735.29 \pm 23.16$ & $265.69 \pm 48.19$ & $316.21 \pm 53.16$ \\
\hline+ & 3 & $269.62 \pm 18.14$ & $584.70 \pm 19.96$ & $163.88 \pm 13.54$ & $315.08 \pm 11.68$ \\
\hline
\end{tabular}

Results are expressed as mean \pm standard deviation of replicates.

treatment had lower $\mathrm{BW}$ and $\mathrm{BWG}$. The results related to FC and FGR are shown in table 4. The AF decreased the FC of birds, difference perceived, but not significant. However, the FC of the birds treated with the AMA-3 plus AF diet was significantly lower. AMA-2 alone, or plus AF, ameliorated the FGR of the birds. The FGR of the T08 broiler chickens was lower, but its BW was down, so this data can't be regarded as good for production parameters.

Summarising, significant differences were observed in all variables (BW, BWG, FC, FCR) between time, presence or absence of AF and/or AMA. These differences are expected, because over the weeks the animals showed an increase in their performance parameters.

Table 5 shows the effects of dietary treatments on the relative weight and histopathological changes of the liver. Microscopically, the livers in chickens fed the diet containing AF showed significant changes and lesions ( $\mathrm{P} \leq 0.05)$ compared to control, such as hepatocyte disorganization and vacuolation, periportal hemorrhage and other characteristics of fatty degeneration. All liver samples of broiler chickens not consuming AF revealed discrete basophilic cell infiltrates in the portal area. The liver samples of broiler chickens consuming AMA-3 plus $\mathrm{AF}$ (T08) revealed the same severe lesions as the livers from animals consuming only AF.

The addition of AMAs did not cause any significant gross and microscopic changes in chicks when compared with the control birds. The addition of AMA-2 and the addition of AMA-3 partially decreased the severity of lesions in the liver, because the aflatoxicosis lesions were observed in lower intensity.

No significant differences were found in the relative weights of the livers $(\mathrm{P} \leq 0.05)$. Macroscopically, the livers from the T03 (AF only) and T08 (AMA-3 plus AF) treatment groups were enlarged and friable and they displayed rounded borders and a yellowish coloration. In the present study, the mixture of YCW, sodium bentonite, and $\mathrm{AF}$ (T08) could not reverse the aflatoxicosis liver effects. 
Table 4. Effects of treatments on temporal feed consumption and on feed-to-gain ratio.

Efectos de los tratamientos sobre el consumo de alimento temporal y sobre el índice de conversión.

\begin{tabular}{|c|c|c|c|c|c|}
\hline \multicolumn{2}{|c|}{ Treatment } & \multicolumn{2}{|c|}{ Feed Consumption (g) } & \multicolumn{2}{|c|}{ Feed: Gain Ratio $\left(\mathrm{g} \mathrm{g}^{-1}\right)$} \\
\hline $\mathrm{AF}$ & AMA & $14 d$ & $21 d$ & $14 d$ & $21 d$ \\
\hline- & - & $404.61 \pm 11.03$ & $545.90 \pm 50.52$ & $1.30 \pm 0.08$ & $1.53 \pm 0.09$ \\
\hline+ & - & $382.12 \pm 33.85$ & $538.85 \pm 39.52$ & $1.34 \pm 0.09$ & $1.47 \pm 0.07$ \\
\hline- & 1 & $419.57 \pm 19.99$ & $534.11 \pm 21.65$ & $1.36 \pm 0.04$ & $1.48 \pm 0.03$ \\
\hline+ & 1 & $392.75 \pm 11.48$ & $555.82 \pm 37.61$ & $1.29 \pm 0.08$ & $1.49 \pm 0.07$ \\
\hline- & 2 & $319.78 \pm 53.03$ & $558.78 \pm 49.59$ & $1.11 \pm 0.12$ & $1.38 \pm 0.08$ \\
\hline+ & 2 & $393.82 \pm 23.56$ & $521.76 \pm 22.72$ & $1.28 \pm 0.06$ & $1.42 \pm 0.03$ \\
\hline- & 3 & $412.17 \pm 29.31$ & $567.35 \pm 67.03$ & $1.33 \pm 0.14$ & $1.53 \pm 0.11$ \\
\hline+ & 3 & $272.30 \pm 19.00$ & $440.79 \pm 61.48$ & $1.27 \pm 0.07$ & $1.34 \pm 0.11$ \\
\hline
\end{tabular}

Results are expressed as mean \pm standard deviation of replicates.

Table 5. Effect of treatments on relative liver weight and microscopic liver changes.

Efecto de los tratamientos sobre el peso relativo del hígado y alteraciones hepáticas microscópicas.

\begin{tabular}{lcccccccc}
\hline Microscopic Changes/Lesions & T01 & T02 & T03 & T04 & T05 & T06 & T07 & T08 \\
\hline Hepatocyte disorganization & - & - & +++ & + & - & + & - & +++ \\
Hepatocyte vacuolation & - & - & +++ & - & - & - & - & +++ \\
Basophilic cell infiltrate in the portal & + & + & +++ & + & + & + & + & +++ \\
Bile duct hyperplasia & - & - & +++ & + & - & - & - & ++ \\
Periportal hemorrhage & - & - & +++ & - & - & - & - & ++ \\
Congestion of the central lobular vein & - & - & +++ & - & - & - & - & ++ \\
Dilation of the sinusoid capillary & - & - & +++ & + & - & - & - & +++ \\
Periportal necrosis & - & - & +++ & + & - & - & - & +++ \\
Relative liver weight & $2.48 \pm 0.21$ & $2.56 \pm 0.23$ & $2.47 \pm 0.18$ & $2.55 \pm 0.15$ & $2.66 \pm 0.25$ & $2.32 \pm 0.14$ & $2.38 \pm 0.44$ & $2.48 \pm 0.11$ \\
\hline
\end{tabular}

Results are expressed as mean \pm standard deviation.

Legend: no change/lesion(-), discrete change/lesion(+), moderate change/lesion(++); intense change/lesion(+++).

\section{DISCUSSION}

Aflatoxin is an important mycotoxin in the poultry industry because of its high toxicity to chickens, occurrence in feedstuffs, and presence in the basic diet constituents, such as corn. All adsorption isotherms were sigmoidal, indicating that the adsorption occurs by a cooperative mechanism, and the mathematical adjustments were made using the Hill model, which has been recommended in the literature as a method to explain the adsorption isotherms of YCW and modified YCW (Yiannikouris et al 2003, 2004 ${ }^{\mathrm{a}}, 2004^{\mathrm{b}}$ ). For the three AMAs, there was little variation in the shapes of the isotherms between different $\mathrm{pH}$ levels; therefore, the values for the maximum adsorption capacity and for the association and dissociation constants maintained small variations, which indicates high efficiency (adsorption minus desorption) in the adsorption process.

The negative effects (performance and liver lesions) of AF in broiler chickens demonstrated in this study have been reported previously (Santin et al 2003, Giacomini et al 2006). The primary effects that have been reported include decreased BWG and FC, and increased FGR (Ortatatli et al 2005, Zhao et al 2010). The deleterious effects of AF in broiler chickens were more intense in the initial phase (up to 21d), but the negative effects on weight gain and performance were persistent.

Numerous strategies for the detoxification/inactivation of mycotoxin-contaminated feed have been proposed; however, methods to detoxify AF-contaminated feed on a large scale and in a cost-effective manner are not available. A new approach to detoxify AF is the use of $\mathrm{YCW}$ in the diet. A few species of yeast are commercially used. Saccharomyces cerevisiae is one of the most widely commercialized species and one of the most effective adsorbents. S. cerevisiae, whose biological value is high, is rich in protein $(40-45 \%)$ and in vitamin B complex (Çelik et al 2003). These YCW products are already used as prebiotics, which improve the performance of broiler chickens, stimulate the immune system, contribute to 
intestinal integrity, and compete with pathogenic microorganisms in the intestinal lumen (Flemming and Freitas 2005, Keller et al 2012, Santos and Grangeiro 2012). In this study, three adsorbents (with different yeast cell walls of $S$. cerevisiae) were tested. The BW, BWG, and FC parameters from 14-day-old chickens were negatively altered by aflatoxicosis. Two of the AMAs were able to reverse these effects. These results agreed with Aravind et al (2003), Çelik et al (2003) and Keller et al (2012) who demonstrated the ability of YCW to ameliorate the adverse effects of AF in growing broiler chickens. The findings of Santin et al (2003) showed that YCW adsorbents ameliorated the FGR of the chickens in the presence or absence of AF, but they did not observe the deleterious effects of birds in experimental conditions with $0.5 \mathrm{mg} \mathrm{kg}^{-1} \mathrm{AF}$. In the present study, the mixture of YCW, sodium bentonite, and AF did not reverse the negative effects of AF on the production parameters.

The liver, kidney, and immune system organs are considered to be targets for AF, and are primarily affected by aflatoxicosis (Ortatatli et al 2005). Macroscopic and microscopic (histopathology) analyses showed the negative effects that AF promoted on the liver. Hepatocyte disorganization and vacuolation, basophilic cell infiltrate in the portal area, bile duct hyperplasia, and congestion of the central lobular vein were damages to the liver observed in this study and are the same changes found by Çelyk et al (2003) and Zhao et al (2010). Additionally, the protective effects of AMA-1 and AMA-2 decreased the severity of the lesions, which agreed with that reported by Çelyk et al (2003), which investigate the protective effect of baker yeast in aflatoxicosis. The YCW did not reverse these effects as demonstrated in the Zhao et al (2010) study, which investigate the protective effect of a mixture of hidrated sodium aluminiumsilicates (HSCAS) isolated and in combination with YCW in broilers exposed to different levels of aflatoxin in diet.

The AMA-3 product did not reverse the negative effects of AF. The lack of efficacy is perhaps due to saturation or limited binding capacity of yeast cell walls and the type and concentration of clay (bentonite) that was used to prepare the AMA-3 product. Similar results were reported in dairy cows by Kutz et al (2009), with mixtures of clay and YCW at 0.5 and $0.56 \%$ of diets containing 170 and $112 \mu \mathrm{g}$ of $\mathrm{AFB}_{1} / \mathrm{kg}$ of feed, respectively. The products were not effective in reducing milk $\mathrm{AFM}_{1}$ concentrations, $\mathrm{AFB}_{1}$ excretion, or $\mathrm{AFB}_{1}$ transfer from feed to milk.

Results from the present study demonstrated that some YCW products may represent an effective alternative for preventing broiler chicken aflatoxicosis when used with other mycotoxin management practices. However, it is well known that signs of aflatoxicosis vary according to the age, health, and nutritional status of the bird, as well as time of exposure to contaminated food. Further studies are needed on the effects of these additives under different conditions of animal health and production.

\section{ACKNOWLEDGEMENTS}

The authors would like to thank the Conselho Nacional de Desenvolvimento Científico e Tecnológico and the Pró-Reitoria de Pesquisa da Universidade Federal de Minas Gerais for its financial support.

\section{REFERENCES}

AOAC. 1990. Official Methods of Analysis.Vol 1. AOAC International, Washington, DC, USA.

Aravind KL, VS Patil, G Devegowda, B Umakantha, SP Ganpule. 2003. Efficacy of glucomannan to counteract mycotoxicosis in naturally contaminated feed on performance and serum biochemical and hematological parameters in broilers. Poult Sci 82, 571-576.

Bartoli A, O Maggi. 1978. Four new species of Aspergillus from Ivory Coast soil. Trans Br Mycol Soc 71, 393-394.

Çelyk K, M Denly, T Savas. 2003. Reduction of toxic effects of aflatoxin by using baker yeast in growing broiler chicken diets. R Bras Zootec 32, 615-619.

Daković A, S Matijasević, GE Rottinghaus, DR Ledoux, P Butkeraitis, Z Sekuli. 2008. Aflatoxin B1 adsorption by natural and copper modified montmorillonite. Colloids Surf B 66, 20-25.

Flemming JS, RJS Freitas. 2005. Avaliação do efeito de prebióticos, probióticos e promotor de crescimento na alimentação de frangos de corte. Arch Vet Sci 10, 41-47.

Galvano F, A Pietri, T Bertuzzi, M Bognanno, L Chies, A De Angelis, M Galvano. 1997. Activated carbons: in vitro affinity for fumonisin B1 and relation of adsorption ability to physicochemical parameters. J Food Protect 60, 985-991.

Geiser DM, JI Pitt, JW Taylor. 1998. Cryptic speciation and recombination in the aflatoxin-producing fungus Aspergillus flavus. Proc Nat Acad Sci 95, 388-393.

Geiser DM, JW Dorner, BW Horn, JW Taylor. 2000. The phylogenetics of mycotoxin and sclerotium production in Aspergillus flavus and Aspergillus oryzae. Fungal Genet Biol 31,169-179.

Giacomini L, F Fick, P Dilkin, CA Mallmann. 2006. Efeitos toxicológicos das aflatoxinas sobre o desempenho e plumagem de frangos. Cienc Rural 36, 234-239.

Gibson GR, PS Karen, RA Rastall, KM Tuohy, A Hotchkiss, A DubertFerradon, M Gareau, EF Murphy, D Saulnier, G Loh, S Macfarlane, N Delzenne, Y Ringel, G Kozianowski, R Dickmann, I LenoirWijnkoop, C Walker, R Buddington. 2010. Dietary prebiotics: current status and new definition. Food Sci \& Technol Bulletin 7, 1-19.

Ito Y, SW Peterson, DT Wicklow, T Goto. 2001. Aspergillus pseudotamarii, a new aflatoxin producing species in Aspergillus section Flavi. Mycol Res 105, 233-239.

Jouany JP, A Yiannikouris, G Bertin. 2005. The chemical bonds between mycotoxins and cell wall components of Saccharomyces cerevisiae have been identified. Arch Zoot 8, 26-50.

Keller KM, AA Oliveira, TX Almeida, LAM Keller, BD Queiroz, LMT Nunes, LR Cavaglieri, CAR Rosa. 2012. Efeito de parede celular de levedura sobre o desempenho produtivo de frangos intoxicados com aflatoxina $\mathrm{B}_{1}$. Rev Bras Med Vet 34,101-105.

Kurtzman CP, BW Horn, CW Hesseltine. 1987. Aspergillus nomius, a new aflatoxin-producing species related to Aspergillus flavus and Aspergillus tamarii. Anton Leeuw 53,147-158.

Kutz RE, JD Sampson, LB Pompeu, DR Ledoux, JN Spain, M VazquezAnon, GE Rottinghaus. 2009. Efficacy of Solis, NovasilPlus, and MTB-100 to reduce aflatoxin $M_{1}$ levels in milk of early to mid lactation dairy cows fed aflatoxin $\mathrm{B}_{1}$. J Dairy Sci 92, 3959-3963.

Manafi M, HNN Murthy, HD Narayana Swamy. 2012. Evaluation of mycotoxin binders on aflatoxicosis in broiler breeders induced with aflatoxin B1. American-Eurasian J Agric \& Environ Sci 4, 429-433.

Ortatatli M, H Oguz, F Hatipoglu, M Karaman. 2005. Evaluation of pathological changes in broilers during chronic aflatoxin and clinoptilolite exposure. Res Vet Sci 78, 61-68. 
Peterson SW, Y Ito, BW Horn, T Goto. 2001. Aspergillus bombycis, a new aflatoxigenic species and genetic variation in its sibling species, A. nomius. Mycologia 93,689-703.

Pitt JI. 1993. Corrections to species names in physiological studies on Aspergillus flavus and Aspergillus parasiticus. J Food Protect 56, 265-269.

Rawal S, JE Kim, R Coulombe Jr. 2010. Aflatoxin B in poultry: Toxicology, metabolism and prevention. Res Vet 89, 325-331.

Reis, TA, AC Baquião, DD Atayde, F Grabarz, B Correa. 2014. Characterization of Aspergillus section Flavi isolated from organic Brazil nuts using a polyphasic approach. Food Microbiol 42, 34-39.

Ringot D, B Lerzy, JP Bonhoure, E Auclair, E Oriol, Y Lanondelle. 2005. Effect of temperature on in vitro ochratoxin A biosorption onto yeast cell wall derivates. Process Biochem 40, 3008-3016.

Rossi P, JK Nunes, F Rutz, JS Reis, D Boursheidt, AA Rocha, PVD Moraes, MA Anciuti. 2013. Glucomanano e selênio em frangos alimentados com dietas com aflatoxinas. Arch Zootec 62, 33-43.

Saito M, O Tsuruta, P Siriacha, M Manabe. 1989. Atypical strains of Aspergillus flavus isolated in maize fields. Jpn Agr Res Q23,151-154.

Salim, A-B, A Zohair, AE-S Hegazy, A Said. 2011. Effect of some Strains of Probiotic Bacteria against Toxicity Induced by Aflatoxins. J Am Sci 7, 772-783.

Santin E, AC Paulillo, EL Krabbe, AC Alessi, WJC Polveiro, A Maiorka. 2003. Use of cell wall yeasts as adsorbent of aflatoxin. Arch Vet Sci 8, 51-55.
Santos, JF and JIV Grangeiro. 2012. Desempenho de aves caipira alimentadas com mandioca e palma forrageira enriquecidas com levedura. Tecnol \& Ciên Agropec 6, 49-54.

Shotwell OL, CV Hesseltine, RD Stubblefield, WG Sorenson. 1966. Production of aflatoxin on rice. Appl Microbiol 14, 425-429.

Yiannikouris A, L Poughon, X Cameleyre, CG Dussap, J Francois, G Berting, JP Jouany. 2003. A novel technique to evaluate interactions between Saccharomyces cerevisiae cell wall and mycotoxins. Biotechnol Lett 25, 783-789.

Yiannikouris A, J Francois, L Poughon, CG Dussap, G Jeminet, JP Jouany. 2004 ${ }^{\text {a }}$. Adsorption of zearalenone by beta-D-glucans in the Saccharomyces cerevisiae cell wall. J Food Protect 67, 1195-1200.

Yiannikouris A, J Francois, L Poughon, CG Dussap, G Bertin, G Jeminet, JP Jouany. 2004 ${ }^{\mathrm{b}}$. Alkali extraction of $\beta$-D-glucans from Saccharomyces cerevisiae cell wall and study of their adsorptive properties towards zearalenone. J Agr Food Chem 52, 3666-3673.

Yiannikouris A, G André, A Buléon, G Jeminet, I Canet, J François, G Bertin, JP Jouany. 2004 . Comprehensive conformational study of key interactions involved in zearalenone complexation with beta-D-glucans. Biomacromolecules 5, 2176-2185.

Zhao J, RB Shirley, JD Dibner, F Uraizee, M Officer, M Kitchell, M Vazquez-Anon, CD Knight. 2010. Comparison of sodium calcium aluminosilicate and yeast cell wall on counteracting aflatoxicosis in broiler chicks. Poult Sci 89, 2147-2156. 